3. Толковый словарь русского языка / Под ред. Д.Н. Ушакова. - М.: Сов. энцикл.: ОГИЗ, 1935-1940.

4. Уголовный кодекс Российской Федерации от 13.06.1996 № 63-Ф3 (ред. от 24.02.2021) // Собрание законодательства РФ. 17.06.1996. № 25. Ст. 2954.

5. Определении Судебной коллегии по уголовным делам Верховного Суда РФ от 1 июня 2010 г. № 81-д10-11 // СПС «Консультант Плюс»

6. Наумов С.Н. Совместность участия как оценочный признак соучастия в преступлении // Общество и право.2009. №3 (25).

7. Комментарий к УК РФ / Под общей редакцией В.М. Лебедева. - М., 2013.

8. Петрушенков А.Н. Научная обоснованность признаков соучастия в преступлении и их практическая реализуемость в нормах Особенной части Уголовного кодекса Российской Федерации // Вестник Нижегородской академии МВД России. 2015. №1(29).

9. Макарова Т.Г. Виды соучастников в уголовном праве. - СПб, 2004.

\title{
Цуканов С.С. \\ Правовые основы избирательной системы РСФСР и их реализация на территории Дальнего Востока России (1923-1926 гг.)
}

Дальневосточный филиал Российского государственного университета правосудия doi: 10.18411/lj-04-2021-259

(Россия, Хабаровск)

\section{Аннотация}

Завершение на материковой части Дальневосточного региона гражданской войны и военной интервенции поставило перед центральными органами власти и Дальневосточным революционным комитетом задачу формирования вертикали советских органов власти. Представленная статья освещает нормативное регулирование и ход избирательной кампании в регионе.

Ключевые слова. РСФСР, Дальний Восток, избирательное право, советские органы власти.

\section{Abstract}

The completion of the civil war and military intervention on the mainland of the Far Eastern region set the central authorities and the Far Eastern Revolutionary Committee with the task of forming a vertical of the Soviet authorities. The presented article covers the regulatory regulation and the course of the election campaign in the region.

Key words. RSFSR, Far East, suffrage, Soviet authorities.

Освобождение территории Дальневосточной Республики (ДВР) от интервентов и белогвардейцев произошло 25 октября 1922 г., когда войска Народно-революционной армии (НРА) заняли Владивосток.

Но окончание боевых действий на фронтах Гражданской войны далеко не означало разрешения всех внешних и внутренних конфликтов в советском обществе. Охватившие не только Дальний Восток, но и всю страну кризисные явления, проявившиеся в забастовочном движении рабочих, в снижении доверия крестьян к проводимой Советской властью и большевистской партией политике на селе, а также в открытых вооруженных выступлениях белогвардейцев. Особую остроту эти выступления приняли на Дальнем Востоке, где на соседней территории Китая, после поражения в Гражданской войне находились большое количество белоэмигрантов, выступавших против советской власти. Трудности восстановления народного хозяйства на Дальнем Востоке усиливались тем, что одновременно надо было создавать советские органы власти, бороться с последствиями интервенции, отбивать попытки иностранных государств, которые стремились затормозить и сорвать укрепление Советской власти в регионе.

Дальневосточный революционный комитет, являлся чрезвычайным органов власти в регионе. Ему предстояло создать на местах избранные на основе Конституции 
РСФСР 1925 г. органы государственной власти и приобщить население края к новой жизни и начать восстановление народного хозяйства. Земства и сельские комитеты на местах были заменены волостными и сельскими ревкомами. Главной задачей ревкомов была подготовка перехода от органов власти, создаваемых по принципу назначения, к выборным Советам.

В период с октября 1922 г. до марта 1923 г. в регионе была образована единая система советских органов. Для работы в ревкомы партийные организации направляли наиболее опытных и проверенных коммунистов. В состав ревкомов входили секретари губревкома и укомов партии, а председатели ревкомов являлись членами партийных комитетов. Губернские и уездные партийные комитеты подбирали руководящий состав уездных и волостных ревкомов.

ЦК РКП (б) своим циркуляром от 1 декабря 1922 г. рекомендовал всем образованным на Дальнем Востоке губревкомам использовать предстоящий зимний период для работы среди крестьян. Среди ключевых задач выделялись:

- усиление влияния партии в деревне;

- популяризация и проведение в жизнь Земельного кодекса РСФСР;

- поднятие дееспособности и авторитета сельских коммунистических ячеек;

- сроднение трудового крестьянства с Советской властью.

Следует отметить, что ревкомы на Дальнем Востоке создавались планомерно, и система организации аппарата управления проходила сверху вниз, т.е. вначале образовывались вышестоящие органы, которые организовали низовой аппарат управления. Создание сети ревкомов на Дальнем Востоке проходило строго централизованным порядком. Дальревком и Дальбюро ЦК РКП (б) боролись с кустарничеством и самостийностью при создании органов власти, т.к. на местах было необходимо создать однотипный аппарат с определенными сферами деятельности. Дальбюро ЦК РКП (б) и Дальревком в своей работе учитывали опыт ДВР, где административные органы на местах зачастую носили неформальный характер с крайней разнородностью структуры и форм. Дальбюро ЦК РКП (б) указывало всем губревкомами РКП (б) «на недопустимость проявления самостийности в государственном строительстве без надлежащих инструкций центра. Неправильные мероприятия затрудняли работу центра, поэтому проявление самостийности Дальбюро рассматривает как нарушение партийной дисциплины». Таким образом, принцип назначения, которым руководствовались при создании ревкомов, обеспечивал централизацию, строгий порядок образования всей системы государственного аппарата на Дальнем Востоке.

Подготовка к выборам в Советы началась в январе 1923 г. По указанию ЦК партии Дальбюро ЦК РКП (б) создало в деревне группы содействия Советской власти. Дальревкому было поручено собрать материал об организации советских аппаратов на местах. 3 марта 1923 г. была образована Центральная избирательная комиссия по выборам в Советы. В состав комиссии входили: от Дальбюро -Н.М. Матвеев, от ДВСПС - К.И. Кнопинский, от 5 Красной Армии - В.А. Смирнов, от общего отдела управления Дальревкома - И.Б. Кацва.

Подводя итоги выборов необходимо отметить, что Советский аппарат Дальнего Востока, в особенности волостной, после перевыборов 1924 г., укрупнения волостей и усиления его новыми работниками значительно окреп. Городские советы в большинстве созывались только на торжественные заседания, но в Чите, Благовещенске, Владивостоке и Хабаровске интенсивную работу вели секции горсоветов. Из недостатков работы советских органов необходимо отметить наличие на тот момент «еще не изжитого в некоторых местах налоготворчества низового состава партийного аппарата». Для пополнения низового аппарата опытными работниками 
Амурским и Приморским губисполкомами организовывались курсы административнохозяйственных работников деревни.

Затем были созданы избирательные комиссии на местах - в губерниях, уездах и волостях. По ходатайству Дальревкома ВЦИК, учтя особые условия Дальневосточной области, снизил по ней нормы представительства по выборам в Советы. 25 августа 1924 г. началась вторая кампания по выборам в Советы, которая проходила под лозунгом укрепления союза рабочего класса с крестьянством и оживления работы Советов.

Предвыборная кампания 1925 г. совпадала с важным событием. В феврале 1924 г. был проведен съезд по районированию Восточной Сибири, а в 1925 г. на основе суммированного экономического описания округов разработано положение по административному делению. Начатое Дальревкомом районирование Дальневосточной области было вызвано необходимостью приблизить к местам и создания более работоспособных органов Советской власти.

Был образован Дальневосточный край, в который вошло 9 округов (75 районов). Губернии и уезды в начале 1926 г. были упразднены.

Таким образом, выборы 1925 г. проходили уже в новых границах округов и районов. Большое внимание было обращено на ход сельскохозяйственной компании. Уже в марте 1925 г. Дальревком отмечал, что в Забайкалье было вполне удовлетворительное состояние по сбору налога. Однако имелось слабое поступление по Амурскому и Приморскому районам. Вместе с тем, Дальневосточный революционный комитет констатировал, что в значительной степени, точка тяжести советского строительства в 1924 г. была перенесена в деревню. Перевыборы советов, хотя и выявили увеличение активности крестьянства, но в большей части сельсоветов не дали полностью ожидаемого числа участвовавших в выборах. Москва установила, что «работу по советскому строительству в деревне на ближайшее время проводить, имея главной задачей всемерное оживление работы сельсоветов и волисполкомов и укрепление их авторитета среди местного населения. Причем, всеми руководящими органами должно быть обращено внимание, чтобы сельсоветы и волисполкому в своей работе были бы не только органами управления, но, одновременно и органами проявления широкой самодеятельности крестьянских масс».

В январе 1926 г. прошли районные и окружные съезды Советов, а в марте в Хабаровске состоялся первый краевой съезд Советов рабочих, крестьянских, красноармейских и казачьих депутатов. Съезд заслушал отчет Дальревкома о советском строительстве в крае с момента перехода власти от ДВР к Советам. Съезд единодушно одобрил деятельность Дальревкома и избрал на основе Конституции РСФСР 1925 г. Дальневосточный краевой исполнительный комитет. Дальревком закончил работу и передал свои функции вновь избранному Далькрайисполкому.

Таким образом, на Дальнем Востоке путь к Советам лежал через демократический «буфер» (ДВР), который потребовал от ЦК РКП (б) тактики лавирования, обусловленной интервенцией и сложной международной обстановкой. Создание системы ревкомов на территории бывшей Дальневосточной республики подготовило базы для установления Советской системы управления. Переход от органов управления ДВР к ревкомам был проведен постепенно. Он не нарушил повседневной деятельности органов власти. К марту 1923 г. Дальневосточное Бюро ЦК РКП (б) и Дальревком, руководимые ЦК РКП (б) и Выбранным Советским правительством, провели ряд мер по формированию органов управления народным хозяйством, реформированию промышленного сектора и введению советского законодательства.

$$
* * *
$$

1. Кулешов, Д.С. Роль органов государственной безопасности в процессе советизации Дальнего Востока: к постановке проблемы / Д.С. Кулешов // Общество : философия, история, культура. 2016. - № 4. - C. 84-86. 
2. Орнацкая, Т.А. Общая теория права: учебно-методическое пособие / Т.А. Орнацкая. - Хабаровск: ХПИ ФСБ России, 2016. - 115 с.

3. Орнацкая, Т.А., Ципкин, Ю.Н. Борьба Советской России и Дальневосточной республики за ликвидацию интервенции на Северном Сахалине в 1920-1925 гг. / Т.А. Орнацкая, Ю.Н. Ципкин // Проблемы Дальнего Востока. - 2008. - № 2. - С. 138-152.

4. Орнацкая, Т.А., Цуканов, С.С. Дальневосточный революционный комитет: цели, задачи, структура / Т.А. Орнацкая, С.С. Цуканов // История государства и права. - 2010. - № 3. - С. 31-35.

5. Ц Цуканов, С.С. Вклад Дальневосточного революционного комитета в развитие региона (1922-1926 гг.) / С.С. Цуканов - Хабаровск, 2017.

6. Цуканов, С.С. Военная реформа 1924-1925 гг. глазами японского разведчика / С.С. Цуканов // Военно-исторический журнал. - 2011. - № 4. - С. 29-37.

7. Цуканов, С.С. Реорганизация органов государственной безопасности СССР в первые месяцы Великой Отечественной войны / С.С. Цуканов // Общество : философия, история, культура. - 2018. - № 1. - С. 99-102.

8. Шабельникова, Н.А. Милиция в системе охраныправопорядка на Дальнем Востоке России в 1920е гг. / Н.А. Шабельникова. - Владивосток: Изд-во ДВФУ, 2019. - 126 с.

9. Шабельникова, Н.А., Шепотько, Л.В., Усов, А.В. История государства и права России / Н.А. Шабельникова, Л.В. Шепотько, А.В. Усов. - М.: Проспект, 2017. - 240 с.

\section{Чимаров Н.С. \\ Конституционно-правовая защита избирательных прав граждан в условиях реализации технологии регистрации по биометрическим показателям: на примере зарубежного опыта}

Северо-Западный институт управления Российской академии народного хозяйства и государственной службы при Президенте РФ

doi: 10.18411/lj-04-2021-260

(Россия, Санкт-Петербург)

\section{Аннотация}

В статье представлен анализ национальной модели новой технологии голосования посредством задействования биометрических показателей избирателей в Кыргызской Республике. Выявляя отдельные стороны нормативно-правового закрепления данной технологии, автор акцентирует внимание на ее потенциале, в части соответствия духу национального конституционализма и укреплению доверия населения к электоральным процедурам инновационного характера.

Ключевые слова: избирательные права граждан, конституционализм, новые технологии голосования, избирательный процесс, выборы, биометрические данные.

\section{Abstract}

The article presents an analysis of the national model of a new voting technology through the use of biometric indicators of voters in the Kyrgyz Republic. Identifying certain aspects of the normative and legal consolidation of this technology, the author focuses on its potential, in terms of compliance with the spirit of national constitutionalism and strengthening public confidence in electoral procedures of an innovative nature.

Keywords: electoral rights of citizens, constitutionalism, new voting technologies, electoral process, elections, biometric data.

Конституционные гарантии основных прав человека и примат верховенства права выступают основой развития конституционализма в странах с развивающейся демократией. В этой связи, представляется важным исследование демократических преобразований в избирательных системах отдельных стран с отмеченным выше уровнем развития демократии. Универсальный характер правовых избирательных стандартов новых технологий голосования способствует динамичному развитию различных избирательных систем. С учетом изложенного, мы считает необходимым наиболее подробно исследовать опыт реализации некоторых электоральных процедур в 